\section{Carter backs Third World technology}

President Carter has proposed setting up a new foundation for technological co-operation to stimulate and support research of direct benefit to developing countries.

No firm decision has yet been made about the form that such a foundation would take. However according to Dr Frank Press, whose Office of Science and Technology Policy is looking at various alternatives, it could eventually achieve a stature comparable to that of the National Science Foundation, whose annual budget is now about $\$ 700$ million.

The proposal for a new foundation was first raised publicly in a speech which President Carter gave in Caracas during his recent visit to South America. Claiming that for the rest of the century the greatest potential for growth lay with the developing world, the president added that "to become more self-reliant, developing nations need to strengthen their technological capabilities".

The proposed foundation would concentrate primarily on developing new technologies, rather than on problems of economic development which are already the concern of other agencies. In addition, the administration emphasises that it would not merely attempt to develop research at home, but that much of the work financed by the foundation would be carried out abroad.

It is hoped that plans will advance sufficiently rapidly for the US to present the creation of the foundation to next year's United Nations conference on Science and Technology for Development.

Meanwhile the National Academy of Sciences has delivered to the State Department a report on the scientific and technological priorities which it feels should be addressed by the US delegation to the UNCSTD conference.

The report, which was prepared by a National Research Council committee chaired by Dr Press's immediate predecessor as presidential science adviser, Dr Guyford Stever, lists 22 unilateral and collaborative initiatives involving US research workers which it suggests should receive most emphasis.

These are grouped into five categories as follows:

Increasing food supplies: Reducing postharvest food losses; soil and water management at the farm level; plant and animal protection; and overcoming biological limits to plant productivity.

-Health and related needs: Delivery of primary health care; pure water and waste treatment; controlling infectious diseases in the tropics; and improved con- traceptives.

-Urbanisation and Industrialisation: Improving urban settlements; planning transportation systems; building capabilities for creating and using industrial technology; and international research on the industrialisation process.

- Management of resources: Development and use of energy; remote sensing and other applications of satellite technology;

sustained, multiple use of forest resources; and research on the marine environment. -General initiatives: Strengthening scientific and technological policymaking; information sharing; education in the United States; short-term, nondegree training; continuing university interchange and incentives for development-related research in the United States.

David Dickson

\title{
UK wants collaboration on water pollution
}

CONCERN in the UK over EEC legislation to control water pollution has prompted the UK Water Research Centre (WRC) to set up a European Division. It is to help bridge the gap on water pollution policy between the UK and the other countries of Europe.

At six-weeks-old, the division is too young to know how it will tackle its task. But Dr T. V. Arden, its director, sees the first priority as making contact with most of the water centres and authorities in Europe to find out what research is being done where. At the moment he feels there is too much overlap of research effort and too little pooling of research results.

Once contact is made pollution scientists should be able to discuss their countries' problems before approaching the EEC with recommendations for action. At present, Dr Arden says, EEC legislation can be initiated by one or two people working on a specific problem relevant to their country. Working through the bureaucratic machinery of the EEC, their recommendations can become legislation having received no substantial input from the scientists of another country. Poorly thought-out policies, which can even be irrelevant to some countries' problems, can be introduced in this way, Dr Arden believes.

A case in point is the EEC directive on the quality of coastal bathing waters. It lays down standards for the concentrations of bacteria in sea water and recommends several methods of measuring them. The directive is particularly inappropriate to the UK, according to Dr Arden. Britain's long coastline would make continual monitoring of bathing waters prohibitively expensive and the heavy seas some- times found around Britain would probably pose more of a hazard to the people taking samples than any bacteria would pose to bathers.

The WRC also questions the validity of measuring bacterial levels at all. The UK Medical Research Council (MRC) sponsored a study some years ago to assess the hazards to health from bacteria in coastal waters. It found that provided the waters are aesthetically acceptable the danger to health is minimal. The study also found that sewage outfall is not the only factor contributing to high bacterial levels: seagulls can also have a marked effect on them.

Work at the WRC has also shown that the concentration of bacteria measured varies with each method recommended by the directive to a far greater extent than generally realised. Many of the methods of counting bacteria already developed apply to potable water and may not be suitable for sea water. One of the centre's current programmes, therefore, is to assess the comparability of the results obtained by the various methods known to be in use.

Dr Arden is confident that the WRC is the best centre of its kind in Europe and feels that it is therefore natural that it should take the lead in increasing collaboration. Some of the other centres excel in specific research topics and he is especially keen to make contact with these. Eventually, he would like to collaborate with some of the international agencies such as the United Nations Environment Programme, but he feels that it will be six months before the division really gets off the ground.

Judy Redfearn 